\title{
GOVERNING SHARED OFFSHORE ELECTRICITY INFRASTRUCTURE IN THE NORTHERN SEAS
}

\author{
VOLKeR RoEBeN*
}

\begin{abstract}
Through the joint 'North Seas Countries Offshore Grid Initiative' the states bordering the North Seas are establishing shared large-scale offshore electricity infrastructure in order to exploit their offshore wind energy resources. The article argues that this international governance of oceans space comes about legally because international law, European law and national law each fulfil a specific function. The climate regime provides the normative impetus, the law of the sea allocates competences, and European law contains principles of cooperation, which are then implemented through coordinated national law. International law, European law and national law thus become functionally integrated. This analysis has significance beyond shared offshore electricity infrastructure. It illustrates the way in which the functional integration of international law, European law and national law is emerging as a distinct legal institution in its own right, separate and distinct from the various legal orders themselves.
\end{abstract}

Keywords: comparative law, concepts of international law, EU law, international and European energy law, international environmental law, law of the sea, public international law.

\section{INTRODUCTION}

'Global climate change is one of the greatest challenges of our time', ${ }^{1}$ and renewable energy from the oceans will play a critical role in mitigating it. ${ }^{2}$ Exploiting the full potential of marine renewable, and above all, wind energy requires feeding this electricity into and distributing it through large-scale offshore infrastructure that spans the marine jurisdictional zones of several states. Designing, installing and operating such a grid is the purpose of the 'North Seas Countries Offshore Grid Initiative' (NSCOGI), signed by the states

* Professor, Swansea University, v.roeben@swansea.ac.uk.

1 The Future We Want, Outcome document of the United Nations Conference on Sustainable Development, para 190, UN General Assembly resolution 66/288, Annex, UN Doc A/RES/66/288 (11 September 2012).

2 The topic of focus of the thirteenth meeting of the United Nations Open-ended Informal Consultative Process on Oceans and the Law of the Sea, 29 May-1 June 2012, was 'marine renewable energies', report on the work of the ICP at its 13th meeting, UN Doc A/67/120, and report of the Secretary General (UN), Oceans and the Law of the Sea, A/67/79 (31 August 2012). 
bordering on the Northern seas, including the UK, and which is to be implemented by $2030 .{ }^{3}$ This initiative is not only of high practical importance, both regionally, for the participating European states,${ }^{4}$ and globally, as a test case in waters with great wind-energy potential, but it is also is an instance of international governance of shared marine energy infrastructure. This article examines the legal form of this novel development in ocean governance which, it is argued, takes the form of international law, European law and coordinated national law working together, with each of these legal orders fulfilling a specific function in order to achieve the overall objective of governing shared marine infrastructure.

The article proceeds as follows. Part II sets out the challenge posed by shared offshore electricity grids for ocean space governance. Parts III-VI then explain how the legal response to this challenge combines international, European and national law. Part III addresses the role of the international climate regime; Part IV considers the role of the law of the sea; Part V looks at the contribution of European law; Part VI examines the role of coordinated national laws. Part VII then analyses the functional integration of international law, European law and national law as a distinct legal phenomenon. By way of conclusion, Part VIII seeks to draw more general lessons from the harvesting of wind energy in the Northern seas for the functional integration of international, European and national law in other spheres.

\section{GOVERNING SHARED OFFSHORE ELECTRICITY INFRASTRUCTURE}

Offshore wind energy generation is a commercial reality. ${ }^{5}$ Yet, exploiting its full potential does not only depend on the generative capacity. It requires an offshore electricity infrastructure connecting the wind energy 'harvested' in offshore waters with onshore centres of consumption. ${ }^{6}$ An offshore electricity grid links wind farms across jurisdictional zones and aggregates the electricity

\footnotetext{
${ }^{3}$ Belgium, Denmark, France, Germany, Ireland, Luxembourg, the Netherlands, Sweden, the United Kingdom, and the European Commissioner for Energy signed the Political Declaration on the 'North Seas Countries' Offshore Grid Initiative' on 7 December 2009 (North Sea, the Channel, Irish Sea, Celtic Sea covering a surface area of about $\left.760,000 \mathrm{~km}^{2}\right),<$ http://www.benelux.int/pdf/ pdf_fr/act/act0170_NorthSeasCountriesOffshoreGridInitiativePoliticalDeclaration.pdf $>$ (NSCOGI).

${ }^{4}$ See UK Parliament, House of Commons Energy and Climate Change Committee, Energy and Climate Change: Seventh Report 'A European Supergrid', September 2011, <http:// www.publications.parliament.uk/pa/cm201012/cmselect/cmenergy/1040/104002.htm> (European Supergrid Report); European Commission (EU), 'Energy Infrastructure Priorities for 2020 and Beyond: A Blueprint for an Integrated European Energy Network' COM (2010) 677, 26 (17 November 2010), approved by the European Council, 4 February 2011, and Council (EU), 28 February 2011 (doc 6207/1/11 REV 1) (Energy infrastructure).

5 European Commission (EU), Renewable Energy: A Major Player in the European Energy Market, SWD (2012) 163.

${ }^{6}$ The European Wind Energy Association, Oceans of Opportunity, 2009, 27, <http://www. ewea.org/fileadmin/ewea_documents/documents/publications/reports/Offshore_Report_2009.pdf $>$ (Oceans of Opportunity). The UK's current Round 3 of wind farm leases extends to the continental shelf. Denmark has the offshore wind tenders of Horns Rev 3 and Kriegers Flak. In the German
} 
output of the several production sites, ${ }^{7}$ thus mitigating the volatility of offshore wind energy production ${ }^{8}$ and securing the stability of supply which is critical for modern economies, an advantage further strengthened if the grid is linked to onshore energy storage facilities. Such a grid also allows trading in energy between the producers, enhancing the efficiency of offshore wind energy exploitation and increasing the return on private investments in wind farms. ${ }^{9}$ The more 'meshed' or interconnected the grid is, the greater are the likely gains from enhanced effectiveness and efficiency. Such gains will be greater again if the grid is extensive in scope, has a large energy capacity and links several national markets. Designing, installing and operating large-scale offshore electricity grids has become possible due to the so-called High Voltage Direct Current (HVDC) technology which permits the transmission of electricity over long distances. Submarine power cables using this technology are then interconnected by way of nodes installed on platforms above water. ${ }^{10}$

However, shared large-scale offshore electricity infrastructure of this nature cuts across the jurisdictional zones of the various states and thus raises issues flowing from the international governance of ocean space. Such governance is based on four legal foundations: first, that there is agreement that states ought to cooperate in the use of ocean space; second, there needs to be a secure allocation of competences concerning ocean use between states as a precondition for such cooperation; third, there need to be agreed principles concerning such cooperation; and fourth, a structure needs to be established within which coordinated decisions can be taken. The NSCOGI aims to establish a shared electricity grid across the Northern seas for the harvesting of its wind energy resources ${ }^{11}$ and it is premised on the belief that these foundations can be provided by international law of the climate and of the sea, European law, and regionally coordinated national law, each of which will be considered in the following sections.

III. THE IMPETUS FOR GRID GOVERNANCE. THE ROLE OF THE INTERNATIONAL CLIMATE REGIME

The international climate regime provides the impetus for the participating states to exploit marine renewable energy through large-scale offshore

EEZ, two clusters are in action, and the large '0ffshore-Windpark Amrumbank West' is planned for 2013-15.

${ }^{8}$ Oceans of Opportunity (n 6) 8-9, 25.

7 Energy infrastructure (n 4) 26.

9 Energy Infrastructure (n 4) 26.

10 ENTSO-E, Offshore Transmission Technology (November 2011, update 16 October 2012) 24, < https://www.entsoe.eu/resources/publications/system-development/north-seas-griddevelopment $>$.

11 The wind energy potential of the Northern seas is investigated through EU-funded projects see Commission (EC), Offshore Wind Energy COM (2008) 768, 9 (13 November 2008). See also Joint Declaration on Cooperation in the Field of Research on Offshore Wind Energy Deployment signed by Germany, Denmark, Sweden and Norway, December 2007, para 8b, <http://www. regjeringen.no/upload/OED/pdf\%20filer/JointDeclaration-D-S-DK-041207.pdf>. 
electricity infrastructure. ${ }^{12}$ The use of renewable energy as a climate change mitigation strategy has been politically required by Agenda $21,{ }^{13}$ the Johannesburg Plan of Implementation, ${ }^{14}$ the outcome document of the Rio +20 conference on sustainable development, ${ }^{15}$ as well as by the G8 Heiligendamm process. ${ }^{16}$ These documents emphasize that advanced technology is a key means of implementation. ${ }^{17}$ The international climate regime based on the 1992 UN Framework Convention on Climate Change ${ }^{18}$ and the 1997 Kyoto Protoco ${ }^{19}$ concretizes these non-binding statements and provides an underpinning of binding international law obligations. Annex I Parties are responsible for taking the lead in mitigation efforts through binding international law, ${ }^{20}$ including quantified emissions reduction obligations under Article 3 of the Kyoto Protocol, and this includes the states bordering the Northern seas. ${ }^{21}$ Article 2(1)(a)(iv) Kyoto Protocol obliges these states to meet their climate commitments, inter alia, by promoting, developing and increasing the use of renewable energies. ${ }^{22}$ This provision spells out policies

12 Energy security points in the same direction, European Council (EU), Presidency Conclusions, 19/20 March 2009, Doc 7880/1/09 REV1, paras 24-28; see B Barton, C Redgwell, A Ronne and DN Zillman (eds), 'Introduction' in Energy Security: Managing Risk in a Dynamic Legal and Regulatory Environment (Oxford University Press 2004) 1, 5.

13 Agenda 21, 1992, paras 4.18, 9.9-9.12 and 9.18, in Report of UNCED, vol I Resolutions Adopted by the Conference, resolution 1, annex II, UN Doc A/Conf.151/26/Rev.1.

14 Johannesburg Plan of Implementation of the World Summit on Sustainable Development, 2002, paras 7(e), 9(a) and (c), 20, 59(b) and 62(j), UN Doc A/CONF.199/20.

15 The Future We Want (n 1) para 128.

16 Report of G8 Renewable Energy Task Force, July 2001, <http://www.g8.utoronto.ca/ meetings-official/g8renewables_report.pdf $>$; Leaders' Declaration, Hokkaido Toyako Summit, Environment and Climate Change, 8 July 2008, para 27, <http://www.mofa.go.jp/policy/economy/ summit/2008/doc/doc080714_en.html>; Leaders' Joint Statement: Promoting the Global Agenda, Annex I 'Concluding Report of the Heiligendamm Process', L'Aquila, Italy, 9 July 2009, paras 40-43, < http://www.g8italia2009.it/static/G8_Allegato/06_Annex_1_HDP_ Concluding.pdf $>$.

17 The Future We Want (n 1), Annex, para 252; and the initiative of the Secretary-General on Sustainable Energy for All, referenced in para 129.

18 United Nations Framework Convention on Climate Change, adopted 9 May 1992, entered into force 21 March 1994, 1771 UNTS 107 (FCCC).

19 Kyoto Protocol to the United Nations Framework Convention on Climate Change, adopted 10 December 1997, entered into force 16 February 2005, 2303 UNTS 148 (KP).

20 Decision 1/CMP.6, 'Outcome of the Work of the Ad Hoc Working Group on Further Commitments for Annex I Parties under the Kyoto Protocol at its Fifteenth Session', preamble para 4 (11 December 2010) in Report of the Conference of the Parties serving as the meeting of the Parties on its Sixth Session, Addendum, Part Two, Doc FCCC/CP/2010/9/Add.1.

21 For the regime's future development see the Durban decisions of 11 December 2011 that foresee a second commitment period from 2013 with QELROs for the EU member states (Decision 1/CMP.7, 'Outcome of the Work of the Ad Hoc Working Group on Further Commitments for Annex I Parties under the Kyoto Protocol at its Sixteenth Session' in Report of the Conference of the Parties serving as the meeting of Parties on its Seventh Session, Addendum, Part Two, FCCC/KP/CMP/2011/10/Add.1).

22 Information on the policies adopted needs to be included in the regular national communications of Annex I Parties to the FCCC Secretariat. 
and priorities, the furtherance of which is an obligation of conduct over time. ${ }^{23}$ It includes using technological means as they become available and (flexible) economic means, including cost-effective transboundary markets. ${ }^{24}$ Parties have to cooperate to that end. ${ }^{25}$ Their cooperation may be aided by the meeting of Parties to the Kyoto Protocol, although that has not yet happened. ${ }^{26}$ The climate regime thus provides the impetus for a policy of cooperative offshore wind energy exploitation through ancillary infrastructure. For realizing this policy objective, however, it looks to external legal frameworks.

\section{COMPETENCES FOR THE GRID. THE LAW OF THE SEA}

The 1982 UN Convention on the Law of the $\mathrm{Sea}^{27}$ lays the groundwork for such cooperation by determining which state is competent for each element of an offshore grid with legal certainty.

\section{A. The Applicability of UNCLOS to a New Use of the Oceans?}

There are, however, a number of objections to the applicability of the UNCLOS framework which need to be addressed. First, the use of offshore grids could not have been foreseen by the drafters of the 1982 Convention, since both the relevant provisions of climate law and the technological advances that make this possible had yet to happen. It may then be argued that a special implementing agreement needs to be negotiated in order to strike an appropriate balance between the interests at stake, as in the case of the

23 S Oberthür and HE Ott, The Kyoto Protocol (Springer 1999) 103, 110. The negotiating history of the subchapeau of art (1)(a) Kyoto Protocol reveals that all proposals included a general commitment to take policies and measures. The uses of not just 'implement' but also 'further elaborate' indicate a dynamic character as the outcome of the negotiations. The policies listed in nos i-viiii are not mandatory but indicative, as reflected in the term 'such as'. See F Depledge, 'Tracing the Origins of the Kyoto Protocol: An Article by Article History', UN Doc FCCC/TP/ 2000/2, art 2(1)(a) paras 40, 42, 53. Generally for obligations of conduct ILC Draft Articles on Responsibility of States for Internationally Wrongful Acts, annexed to GA Resolution 56/117, Commentary on art 12, para 11, in Report of the ILC, Fifty-third session, UN Doc A/56/10.

24 cf art 2(1)(a)(v) Kyoto Protocol, 'market instruments'.

25 Art 2(1)(b) first sentence Kyoto Protocol in connection with art 4(2)(e)(i) FCCC requires Annex I Parties to coordinate on renewables, including relevant economic and administrative instruments. Art 2(1)(b) second sentence Kyoto Protocol covers information sharing. See F Depledge (n 23) art 2(1)(b) para 8.

26 Art 2(1)(b) third sentence Kyoto Protocol empowers the meeting of the Parties to facilitate such cooperation, and art 2(4) Kyoto Protocol to coordinate national policies and measures, for instance through a code of best practice. Cooperation between Annex I and non-Annex I Parties on renewable technology is fostered under art 4(5) FCCC for which an implementing framework was agreed as part of the Marrakesh Accords. In addition, the cooperative flexible mechanisms Clean Development Mechanism (CDM) and Joint Implementation apply to renewables, and methodologies have been developed by the Executive Board of the CDM.

27 United Nations Convention on the Law of the Sea, adopted 10 December 1982, entry into force 16 November 1994, 1833 UNTS 397 (UNCLOS or Convention). 
Agreement on Part XI or the UN Fish Stocks Agreement. ${ }^{28}$ However, these agreements modify or concretize certain Convention provisions or principles and this does not mean that a special implementing agreement is required whenever a new use of the ocean arises. Second, it might be objected that Article 59 of the Convention assumes that there may be lacunae in its allocation of competences, for instance because of factual developments, that need to be dealt with on the basis of equity and all relevant circumstances. But Article 59 provides a residual resolution mechanism only in those cases where the Convention provisions fail to provide an answer after they have been interpreted in accordance with Articles 31, 32 Vienna Convention on the Law of Treaties, ${ }^{29}$ including dynamic interpretation in the light of changed circumstances. $^{30}$

In the present context, such dynamic interpretation relates to the issue of whether HVDC power cables can be brought within the UNCLOS framework. The 1884 Cable Convention, the model for subsequent codifications of the law of the sea as regards cables, only concerns communication cables. ${ }^{31}$ Until recently, practical interest in cable laying has been focused on such cables which are today made of fibre glass rather than copper. ${ }^{32}$ But the 1956 ILC Draft Articles on the Law of the Sea already extended the notion of cables to include power cables ${ }^{33}$ and this understanding informed the 1958 Geneva Conventions and subsequently UNCLOS. ${ }^{34}$ Submarine cables within the

28 Agreement Relating to the Implementation of Part XI UNCLOS, adopted 28 July 1994, entry into force 28 July 1996, 1836 UNTS 42; Agreement for the Implementation of the Provisions of UNCLOS Relating to the Conservation and Management of Straddling Fish Stocks and Highly Migratory Fish Stocks, adopted 4 December 1995, entry into force 11 December 2001, 2167 UNTS 88.

29 Vienna Convention on the Law of Treaties, done 23 May 1969, entry into force 27 January 1980, 1155 UNTS 331 (VCLT).

${ }^{30}$ Responsibilities and Obligations of States Sponsoring Persons and Entities with Respect to Activities in the Area, Advisory Opinion, ITLOS Sea-bed Disputes Chamber, 1 February 2011, paras 57-58; Case Concerning the Gabčikovo-Nagymaros Project (Hungary v Slovakia) (1997) ICJ Reports 7, para 112.

31 Convention for the Protection of Submarine Telegraph Cables, adopted 14 March 1884, entry into force 1 May 1888, British and Foreign State Papers, Vol. LXXV 357-367; 163 CTS 391, Australian Treaty Series 1901 No 1 (electronic), as amended by the Declaration on the Protection of Submarine Cables of 1 December 1886 and the Protocol on the Protection of Submarine Cables of 7 July 1887 (Cable Convention) <http:/www.iscpc.org/information/ Convention_on_Protection_of_Cables_1884.pdf $>$.

32 See S Coffen-Smout and G Herbert, 'Submarine Cables: A Challenge for Ocean Management' (2000) 24 Marine Policy 441; E Wagner, 'Submarine Cables and Protections Provided by the Law of the Sea' (1995) 19 Marine Policy 127. Submarine cables for climate monitoring and disaster warning are considered by the ITU, IOC/UNESCO and the World Meteorological Organization, Oceans and the Law of the Sea (n 2) para 57.

${ }^{33}$ ILC Draft Articles concerning the Law of the Sea, art 61(1) read as follows: 'All States shall be entitled to lay telegraph, telephone of high-voltage power cables and pipelines on the bed of the high seas'. See commentary on draft art 61, para 3; commentary on art 27, para 4, in Report of the ILC, Eighth session, ILC Yb 1956, vol II, Part Two (1956 ILC Draft Articles).

34 Art 61(1) of the 'Text of the articles' adopted by the Second Committee of the First UN Law of Sea Conference only mentions 'submarine cables', UN Doc A/CONF.13/L.17/Add.1, Official 
meaning of UNCLOS thus already include power cables, including the large power cables with HVDC technology that will be used in the construction of any offshore grid. This is an example of the dynamic interpretation of the Convention to changed factual circumstances. The Convention is therefore applicable to the central element of offshore grids and consequently to this novel use of the oceans.

\section{B. Allocating Jurisdiction over Cables, Installations and Wind Energy}

The principal contribution of UNCLOS to offshore grid governance lies in determining the regulatory competence over the individual elements of which such governance comprises. The Convention does so through its usual sectoral approach. Under that approach, the Convention allocates jurisdiction to states for any given ocean use through one of two models: the competence of all states (the flag state principle) or the competence of a single state, the coastal state. Since the North Sea is entirely comprised of either the exclusive economic zones (EEZs) or equivalent zones and the continental shelves of the states bordering it, ${ }^{35}$ these zones will be considered in the following two subsections.

\section{The right of all states to lay cables on the continental shelf}

The competent regulator for cable laying and operation beyond the territorial sea is the flag state. This follows from the provisions on submarine cables in Part VI of the UNCLOS concerning the continental shelf. ${ }^{36}$ Article $79(1)$ grants all states, the coastal state and other states, the right to lay such cables on the continental shelf, ie to regulate the activity and to reap its benefits. The right also comprises ancillary operational activities, on the basis of Article 79(2) and

Records, Vol IV, Annex. This was meant to comprise all cables and achieve terminological unification across the articles, see Proposal by USA, Doc A/CONF.13/C.2/L.108; and the earlier proposal by Italy, Doc A/CONF.13/C.2/L.102. The previous debate in the committee had shown the extension of the right to lay cables to power cables as suggested by the 1956 ILC Articles to be uncontroversial, Official Records, 30th meeting, para 16 (France); para 18 (Italy), para 22 (Venezuela). The uniform terminology of submarine cables was then retained in arts 2, 26 of the High Seas Convention and art 4 of the Continental Shelf Convention.

35 The United Kingdom has claimed an 'Exclusive Fisheries Zone' under the Fisheries Act 1976 section 1, where it exercises rights equivalent to an EEZ in the water column. Sections 84-89 of the UK Energy Act 2004 (EA 2004) established Renewable Energy Zones (REZ), founded in art 56(1)(a) UNCLOS. Schedule 4 para 1 of the UK Marine and Coastal Access Act 2009 amended EA 2004 section 84(4) so that REZ and EEZ now are basically identical; see G Plant, 'Offshore Renewable Energy: Smooth Permitting, Environmental Assessment and Fair Use Allocation' (2003) 13 Journal of Water Law 85.

36 Literature on submarine cables let alone high voltage power cables is scant. Recent contributions are C Redgwell, 'International Regulation of Energy Activities' in M Roggenkamp, C Redgwell, I Del Guayo and A Rønne (eds), Energy Law in Europe (2nd edn, OUP 2007) 13, 63-4; R Zeuschner, 'Pipelines and Cables: The Offshore Transportation of Oil, Gas and Renewable Energy’ (2011) International Energy Law Review 311. 
(5), which guarantee unimpeded maintenance and repair of cables. In line with historical developments, ${ }^{37}$ Article 79 thus safeguards the right of cable laying on the continental shelf, which is defined generally by Article 87(1)(c) as a high seas freedom and is strengthened by Article 112 which provides a 'right' to lay cables on the seabed of the high seas which is opposable to other states and enforceable against private actors. ${ }^{38}$ As is the nature of all high seas rights and freedoms, the flag state principle applies and it is the flag state, be it a coastal or other state, which has the authority to regulate cable laying by persons under its jurisdiction.

All states may thus lay cables freely on any continental shelf without having to consult on the delineation of the course of the cable. The coastal state must give its consent. ${ }^{39}$ Whilst the coastal state may impose reasonable restrictions on cable laying in order to safeguard its exclusive rights to explore the continental shelf and to exploit its resources, according to Article 79(2) these restrictions must not impede the laying or maintenance of cables by flag states. The coastal state cannot take measures to prevent pollution from cables, nor can it determine the course of any cables laid on its continental shelf by other states. This results from the clear wording of Article 79(2), (3) which, whilst granting these rights to coastal states in relation to pipelines on its continental shelf, does not do so as regards cables. This bifurcation may surprise. Yet the Convention's negotiating history 'confirms' within the meaning of Article 32 VCLT that it was indeed intended that the general rights of the coastal state to reduce pollution and to delineate courses should only apply to pipelines and not cables. A proposal made in the Sea-Bed Committee had sought to make the delineation of the course of both pipelines and submarine cables by a foreign state subject to coastal state consent. ${ }^{40}$ Indeed, this had already been suggested by the ILC in its 1956 commentary on draft Article 61(2), paragraph 3, but this was not reflected in Article 4 of the 1958 Continental Shelf Convention. At UNCLOS III, the draft produced by the Evensen group of juridical experts only required coastal state consent for the delineation of the course of pipelines and only referred to the prevention of pollution from pipelines by coastal states. ${ }^{41} \mathrm{It}$ is not apparent why the Evensen group restricted the requirement of coastal state consent to the delineation of the course of pipelines. The fact that the draft also provided for coastal state control over pollution from pipelines suggests

37 cf Cable Convention (n 31) art I.

38 See RR Churchill and AV Lowe, The Law of the Sea (3rd edn, Manchester University Press 1999) 205-7, 455 (cable laying freedom of 'immersion' involving the seabed).

39 See 1956 ILC Draft Articles (n 33), commentary on art 61(2) - which corresponds to art 79(2) UNCLOS: '(t)he coastal State is obliged to permit the laying of cables'.

40 Report of the Committee on the Peaceful Uses of the Sea-Bed and the Ocean Floor beyond the Limits of National Jurisdiction, vol V, UNGA, Official Records, Twenty-eighth Session, Supplement No 21 (A/9021) (China).

41 The Continental Shelf (1075, mimeo.) art 6 (Informal Group of Juridical Experts), reproduced in R Platzöder, Third United Nations Law of the Sea: Documents vol XI (Oceana Publications 1987) 501, 502. 
that it was concerned about the specific environmental pollution threat which they posed, with this justifying extending coastal state powers over pipelines but not over cables. The Informal Single Negotiating Text (ISNT) followed the Evensen draft. ${ }^{42}$ Coastal state efforts at the conference were then concentrated on making the laying of pipelines subject to coastal state consent. ${ }^{43}$ It was argued that there was 'a very great difference between the laying of a cable and the laying of a pipeline', presumably with respect to the potential harm that pipeline spillage may cause to the coastal state's marine environment. ${ }^{44}$ The Informal Composite Negotiating Text (ICNT), which contained what, in essence, became Article 79 of the Convention, continued to only require that the coastal state consent to the delineation of the course of a pipeline traversing its continental shelf. ${ }^{45}$

This is confirmed by the structure of Article 79(4) which sets out the competences of the coastal state in respect of cables. Cables may only enter in a coastal state's territorial sea with its consent, and this also covers grid cables connecting to a landing point onshore. Thus, unlike the continental shelf, states have to obtain the consent of the coastal state to lay a cable within its territorial sea, and the coastal state may set conditions regarding the route of the cable and impose transit charges. ${ }^{46}$ This would also apply to interconnector cables between two countries that connect to the national grid of a coastal state. ${ }^{47}$ According to Article 79(4), the coastal state has jurisdiction over those cables used 'in connection' with the 'exploration and exploitation of the shelf's natural resources'. This does not cover grid cables serving wind energy harvested above water. However, the coastal state also has jurisdiction over cables used 'in connection' with 'the operation of artificial islands, installations and structures under its jurisdiction'. Wind farms located on the continental shelf are examples of such installations and cables connecting such wind farms to an offshore electricity grid are ancillary to them. As a consequence, the coastal state has jurisdiction over such export cables, including the delineation of their course. ${ }^{48}$ Since the large interconnector cables between states and the

42 A/CONF.62/WP.8/Rev.1/Part II, art 65.

43 Proposal by Denmark (1977) (mimeo.) art 67 (RSNT II), reproduced in IV Platzöder (n 41$) 470$.

138th plenary meeting (1980) para 150, XIV Off. Rec. 61 (Denmark).

45 A/CONF.62/WP.10 (ICNT, 1977) art 79, VIII Off. Rec. 1, 17.

46 The coastal state may in turn provide for their protection limiting innocent passage, art 21(1)(c). A vessel used for laying cables is not in innocent passage within the meaning of art 19, see M Mudrić, 'Rights of States Regarding Underwater Cables and Pipelines' (2010) 29 Australian Resources Energy Law Journal 235, 236.

${ }^{47}$ In the case of the 2011 UK-Netherlands Interconnector 'BritNed' the respective national TSOs formed a joint venture to fund and operate the interconnection, which was licensed by both the UK and the Netherlands. The 'NordLink' interconnector from Norway to Germany planned to be laid on the Norwegian, German and Danish continental shelves is registered in Norway and will require licensing both there and in Germany.

48 This is also practice of the offshore wind generation projects in the Northern seas, where foreign producers have assumed responsibility also for the offshore grid system, while the national TSO is responsible for the onshore connection. Examples are 'Rödsand II', which lies between the 
platform to grid connections do not serve to 'operate' specific wind farms, they do not fall under the exclusive jurisdiction of the coastal state, but under the normal rules of flag state jurisdiction. The Convention thus attributes cable laying competences on the continental shelf on the basis of traditional high seas freedoms, with functionally limited exclusive coastal state rights. The Convention provides a coordinating mechanism in respect of the overlapping rights by states, by stipulating in Article 79(5) that all states engaged in laying cables must have due regard for cables already in position, as well as not prejudice the repair of existing cables. ${ }^{49}$ Article 58 also safeguards the high seas freedom of all states, including the coastal state, to lay cables in the water column of the EEZ. Article 58 accords Article 79 lex specialis status for cables insofar as the continental shelf is concerned ${ }^{50}$ and addresses both the laying and the subsequent operation of submarine cables from specialized ships. The operation of the submarine cable is a 'lawful use of the sea related' to the freedom of cable laying and according to Article 58(2) the flag state is exclusively competent to prescribe and enforce the rules that fall within the scope of Articles 113-115. Accordingly, the flag state is to enact those laws and regulations 'necessary' to ensure protection of cables from interference by private parties. ${ }^{51}$ These are obligations of conduct for the flag states. ${ }^{52}$ The flag state is also required, by Article 58(3), to ensure that those involved in cable laying comply with coastal state laws and regulations pertaining to the water column. ${ }^{53}$ Such rules may relate to the exclusive rights and competences of the coastal state for the exploitation of the natural resources of the EEZ and the protection of its marine environment. Such coastal state rules are to be complied with if they are 'in accordance with the Convention' or 'other rules of international law not incompatible' with Article 58(1). ${ }^{54}$ By binding coastal

German island of Fehmarn and the Danish island of Lolland and 'London Array' in the Thames Estuary.

49 cf Dispute Concerning Delimitation of the Maritime Boundary between Bangladesh and Myanmar in the Bay of Bengal (Bangladesh/Myanmar), ITLOS case No 16 (14 March 2012), paras 475-476, for due regard obligations of states under the Convention.

50 This follows from the cross-reference of art 58(1) to art 87(1)(c), which subjects the freedom to lay cables on the continental shelf to Part VI. But see also D Nelson, 'Submarine Cables and Pipelines' in R-J Dupuy and D Vignes (eds), A Handbook on the Law of the Sea (Martinus Nijhoff 1991) vol II, 977, 986, who sees art 56(3) as pertinent. But art 56 does not cover cable laying.

51 See Churchill and Lowe (n 38) 209. Cable Convention (n 31) art VIII, also allocates jurisdiction on these matters to the flag state.

52 cf Case Concerning Pulp Mills on the River Uruguay (Argentina v Uruguay), (2010) ICJ Reports 14, para 187; Responsibilities Opinion (n 30) para 111.

53 See Mudrić (n 46) 247-8; MP Green and DR Burnett, 'Security of International Submarine Cable Infrastructure: Time to Rethink' in MH Nordquist, R Wolfrum, J Norton Moore and R Long (eds), Legal Challenges in Maritime Security (Martinus Nijhoff 2008) 557; S Kaye, 'International Measures to Protect Oil Platforms, Pipelines, and Submarine Cables from Attack' (2007) 31 TulMarLJ 377, 398.

54 For the Northern seas states, European law on the marine environment and namely the Directive (EC) No 92/43 on the conservation of natural habitats and of wild fauna and flora, [1992] OJ L 206/7 may be such rules of international law not incompatible with art 58(1). 
state powers in this way, Article 58(3) ensures that rules adopted by coastal states under Article 56 do not unduly interfere with the right of flag states to lay cables under Article 58(1). Article 79(5) on due regard for all cables, Article 79(2) on safeguarding mineral exploitation rights and Article 58(3) then provide the bases for the coastal state to balance the right to lay cables on the continental shelf with competing uses of the seabed and the water column. ${ }^{55}$

The UNCLOS regime is therefore sufficiently flexible to absorb these technological developments within Article 79(1)-(5) and the need for coordination with competing uses of the sea. This is particularly important since it is unclear whether Article 79 in part or as a whole reflects customary international law. The recent ICJ judgment in Colombia/Nicaragua emphasizes that 'several of the most important provisions' of UNCLOS are reflective of customary international law, ${ }^{56}$ and it acknowledges that a Convention provision can form an 'indivisible regime' in customary law. ${ }^{57}$ That might be relevant to Article 79, paragraph 1 of which is arguably fundamental and paragraphs $2-5$ of which might then form part of an 'indivisible regime', 58 although views in the literature are divided on this. ${ }^{59}$

\section{Exclusive competences of the coastal state for wind energy exploitation and connector nodes of the grid}

In sharp contrast with the law on cables, UNCLOS provides that the coastal state is the sole competent regulator for both the wind energy fed into the grid and the above water connector nodes of the grid. The lead provisions on these uses of the water column are found in Part V on the EEZ, which provides that the coastal state has the exclusive right to exploit the non-living resources of the water column, including wind energy. ${ }^{60}$ This pertains both to regulation of wind energy production and reaping its economic value when fed into a grid.

55 The UK Crown Estate's permission is needed for the rights to lay, maintain and operate cables and pipelines on the seabed within $12 \mathrm{~nm}$ for which it is landlord. It only asks to be informed of cables and pipelines that transit the UK continental shelf, as other activities may be impacted. Other states such as Germany pursuant to the Federal Law on Mining subject all cables to an authorization procedure in regard to conflicting activities. The 'NorNed' interconnector cable from Netherlands to Norway thus required authorization to transit the German EEZ. For practice in Asia see Y Takei, 'Law and Policy for International Submarine Cables in the Asia-Pacific Region', AsianSIL Working Paper 2010/13, fns 39-42.

56 Territorial and Maritime Dispute (Nicaragua v Colombia), Judgment of 19 November 2012 (nyr) para 138

57 Para 139 (there Art 121 paras 1 through 3 on islands).

58 A Party to UNCLOS may be required to comply with art 79 even vis-à-vis a non-Party given the Convention's forming the 'legal order' of the oceans; cf Colombia v Nicaragua, para 126.

59 Compare R Beckman, 'Submarine Cables: A Critically Important but Neglected Area of the Law of the Sea', Indian Society of International Law, 7th International Conference on Legal Regimes of Sea, Air, Space and Antarctica, 15-17 January 2010, New Delhi, 3 with DR Burnett, 'Testimony before the US Senate Committee on Foreign Relations', October 2007, 2-3.

${ }^{60}$ UNCLOS, art 56(1)(a). cf D Leary and M Esteban, 'Climate Change and Renewable Energy from the Ocean and Tides: Calming the Sea of Regulatory Uncertainty' (2009) 24 International Journal of Marine and Coastal Law 617, 617. 
The coastal state is the sole competent regulator for the above water connector nodes of offshore grids, since these 'installations or structures' facilitate the commercial exploitation of wind energy harvested in the EEZ and thus the economic exploitation of the EEZ, in accordance with Articles 60(1)(b) and 56 (1)(a). The coastal state's comprehensive rights in relation to such installations are set out in detail in Article 60(2)-(8), which, by virtue of Article 80, are also applicable to the continental shelf. ${ }^{61}$

\section{Marine environmental protection}

Determining which state has competence in respect of the various elements of the grid is the critical connecting factor as regards the obligations contained in the Convention regarding marine environmental protection. Part XII UNCLOS imposes on all states parties the obligation to protect and preserve the marine environment. ${ }^{62}$ This is balanced with the duty to respect the rights of third states, provided for in Article 194(4). This general obligation is concretized by a series of specific standards that are applicable to offshore electricity infrastructure. They relate to: controlling pollution of the marine environment, including the introduction of 'energy' (Article 1(1), (4)); controlling pollution from 'the use of technologies under their jurisdiction or control' (Article 196(1)), which includes HVDC technology; minimizing pollution 'to the fullest possible extent' from 'installations and devices' operating in the marine environment (Article 194(3)(d)). 'Installations' include the nodes and platforms of the grid and the term 'devices' might be understood to extend to cables. This follows from Article 194(3)(c) on 'devices' used for the resources of the sea-bed.

Protection and preservation of the marine environment in this respect encompasses measures for preventing accidents and dealing with emergencies, ensuring the safety of operations, and regulating the design, equipment, and operation of such installations or devices. Measures must also be taken in the planning and operation of the offshore grid to protect and preserve rare or fragile ecosystems as well as the habitat of depleted, threatened or endangered species and other forms of marine life (Article 194(5)). These are obligations of due diligence that depend on the level of risk and the activities involved and may vary over time. ${ }^{63}$ They are concretized by supplementary principles such as 'use of best environmental techniques' 64 and 'the precautionary approach'. ${ }^{65}$ The Convention also prescribes the use of environmental impact

\footnotetext{
61 cf KN Scott, 'Tilting at Offshore Windmills: Regulating Wind Farm Development within the Renewable Energy Zone' (2006) 18 JEL 89, 96.

${ }^{62}$ UNCLOS, art 192.

63 Responsibilities Opinion (n 30) paras 117-120. Including safe navigation, see IMO resolution A. 671(16) of 19 October 1989 on safety zones and safety of navigation around offshore installations and structures.

65 Responsibilities Opinion paras 122, 135.
} 
assessments, if only in general terms. ${ }^{66}$ The national legislation to prevent, reduce and control pollution of the marine environment from the seabedrelated activity of the grid must be 'no less effective than international rules, standards and recommended practices and procedures' ${ }^{67}$ These standards are subject to continuous development by competent organizations.

\section{Developing International Grid Governance under the Law of the Sea}

It emerges from the above that, with certain exceptions, the Convention provides that cable laying in the EEZ or continental shelf is the right of every state, while wind energy exploitation and regulation of above water installations are exclusive coastal state rights. This right of all states to lay cables in the EEZ of coastal states is judicially enforceable through the procedures of Part XV Section 2 (Article 297(1)(a)), as is the concomitant obligation of the flag state to comply with coastal state laws when doing so (Article 297(1)(b)). The Convention approach is thus one of 'nationalizing' energy infrastructure rather than submitting it to an 'internationalizing' regulatory principle. The former refers to empowering individual states to act in their national interest, the latter to states acting in a common interest. ${ }^{68}$ Consequently, matters concerning energy infrastructure are covered by national law, and there is as yet almost no international law directly applicable to marine (renewable) energy or on transmission infrastructure. ${ }^{69}$ Exercising their competences under the Convention, the states bordering the Northern seas have so far encouraged national point-to-point solutions connecting their offshore wind farms with one national onshore landing point. ${ }^{70}$

National regulation of ocean space uses will often yield overall efficient outcomes. ${ }^{71}$ Yet, as the efficient exploitation of offshore wind energy depends on large-scale electricity infrastructure, states need to cooperate across jurisdictional zones on the basis of a common objective and by coordinating the exercise of their respective rights over wind energy, cables, and installations accordingly. This is certainly so for states operating in the particular geographical context of the Northern seas and in comparable

${ }^{66}$ UNCLOS, art 206 and customary international law give little guidance on their conduct, Responsibilities Opinion (n 30) para 149; cf Pulp Mills on the River Uruguay (n 52) para 205.

67 cf UNCLOS, art 208(3); also art 211(2).

68 See R Wolfrum, Die Internationalisierung staatsfreier Räume (Springer 1984).

69 For renewable energy Leary and Esteban (n 60) 617; A M-Z Gao and K Y-C Juang, 'The International Legal Regime on the Exploitation of Offshore Geothermal, Wave, Tidal and OTEC Energy: In Search of Legal Challenges and Solutions' (2006) 24 International Energy Law and Taxation Review 267. For non-renewable energy further E Üsenmez, 'The UK's Energy Security' in J Paterson, G Gordon and E Üsenmez (eds), Oil and Gas Law: Current Practice and Emerging Trends (Dundee University Press 2011) 33.

${ }^{70}$ See Offshore Transmission Technology (n 10).

71 See E Posner and A Sykes, 'Economic Foundations of the Law of the Sea' (2011) 104 AJIL 569. 
settings. But in principle this holds true whenever states intend efficiently to exploit their offshore wind energy resources. ${ }^{72}$ Such cooperation includes joint planning of a grid, authorization and regulatory oversight, and transborder cost sharing. No conflict with UNCLOS arises, since Parties remain free to exercise their conventional rights in any way they prefer, including cooperatively. To the contrary, the Convention provides the basis for cooperation by determining in a legally certain manner what each state may do in regard to offshore electricity infrastructure.

The question then is whether UNCLOS also contains a model for the cooperative exercise of these competences. While the Convention specifies a range of models for cooperative oceans governance, none of them fits here. It is true that the North Sea meets the definition of an enclosed or semi-enclosed sea contained in Article 122. ${ }^{73}$ Article 123 provides that the states bordering such seas should cooperate in the exercise of their 'rights' under the Convention. But Article 123 only addresses the management of living resources and marine environmental protection, subject matters that are also the object of other provisions concerning cooperation elsewhere in the Convention. Marine renewable energy exploitation by means of cables and installations does not figure here. Nor can it be brought in through interpretation. Arguments for an extensive interpretation could be based on Article 31(1) VCLT, according to which UNCLOS and its individual provisions need to be seen in light of their object and purpose, ${ }^{74}$ or on the basis of Article 31(3)(c) VCLT, which requires that account be taken of external 'relevant rules of international law applicable in the relations between the parties', including other conventions, ${ }^{75}$ such as international climate regime based demands for cooperation on marine renewable exploitation. Both arguments presuppose that the treaty provision under consideration is open textured, ${ }^{76}$ which is the case for Article 123 UNCLOS. Yet neither Article 31(1) nor Article 31(3)(c) VCLT may be used to turn treaty law on its head, ${ }^{77}$ which would be the result if Part XI UNCLOS

${ }^{72}$ For wind energy projects in Asian-Pacific countries supported by regional cooperation see M Esteban and D Leary, 'Current Developments and Future Prospects of Offshore Wind and Ocean Energy' (2012) 90 Journal of Applied Energy 128. Cooperative fora on offshore grids would be the International Renewable Energy Agency and the International Energy Agency; cf Oceans and the Law of the Sea (n 2) para 61.

73 P Birnie, A Boyle and C Redgwell, International Law and the Environment (3rd edn, OUP $2009) 394$.

74 cf Pulp Mills on the River Uruguay (n 52) paras 58-63.

75 Case Concerning Oil Platforms (Iran v USA), (2003) ICJ Reports 161, para 41; Pulp Mills on the River Uruguay (n 52) para 66.

76 ILC Study Group, Fragmentation of International Law, Difficulties Arising from the Diversification and Expansion of International Law, Report, para 467, UN Doc A/CN.4/L.682, and Draft Conclusions, para 20(a), UN Doc A/CN.4/L.682/Add.1, in Report of the ILC, Fifty-eighth session, UN Doc A/61/10; ILC Yb 2006, vol. II, Part Two (Report on Fragmentation).

77 cf Case Concerning the Arrest Warrant of 11 April 2000 (Democratic Republic of the Congo $v$ Belgium), Joint separate opinion of Judges Higgins, Kooijmans and Buergenthal, (2002) ICJ Reports 86, para 79; Report on Fragmentation, paras 473-475. 
were extended to matters that the Convention otherwise makes subject to national regulation. ${ }^{78}$ State practice corroborates this analysis, for instance, cooperative action under the Convention for the Protection of the Marine Environment of the North-East Atlantic has been limited to setting marine environmental standards for wind farms. ${ }^{79}$ Finally, the Convention does not contain a general obligation for its Parties to cooperate. ${ }^{80}$ Of course, the obligation to cooperatively protect the marine environment from the effects of any use of the sea in transborder settings is well established both under the Convention and under customary international law. ${ }^{81}$ But this obligation cannot easily be extended to cooperation on using the oceans to mitigate climate change, ${ }^{82}$ and, in any event, it does not establish benchmarks for such cooperative action in this matter.

Yet the Convention is not a closed catalogue as regards cooperative oceans governance. To the contrary it is open towards novel forms. This openness is reflected in the jurisprudence of the International Tribunal for the Law of the Sea, which seeks to proceduralize and operationalize the idea of cooperation on ocean matters of common concern. ${ }^{83}$ This includes regional mechanisms such as the European Union (EU).

78 The MOX Plant Arbitration (2003) demonstrated differing views about the implications of UNCLOS, art 123 for regional cooperation. But even Ireland's argument that the UK was insufficiently cooperative on measures to defend against terrorist attacks on the Sellafield nuclear plant turned on the attendant environmental obligations of the UK, rather than on nuclear energy use as such. Permanent Court of Arbitration, MOX Plant Case (Ireland v UK) (2003, withdrawn); ITLOS, The MOX Plant Case (Ireland v United Kingdom) (Provisional Measures) Case No 10 (3 December 2001).

${ }^{79}$ Convention for the Protection of the Marine Environment of the North-East Atlantic, adopted 22 September 1992, entry into force 25 March 1998 (OSPAR). OSPAR has issued guidance on the location, operation and removal of offshore wind farms, including associated power cables, OSPAR 'Guidance on Environmental Considerations for Offshore Wind Farm Development' (2008-3). OSPAR's definitions of offshore installations and offshore pipelines underscore its restricted remit, see Decision 98/3 on the Disposal of Disused Offshore Installations, excluding 'any part of an offshore installation which is located below the surface of the sea-bed'.

${ }^{80}$ UNCLOS sets forth discrete cooperative obligations. The Responsibilities Opinion (n 30) paras 142-143, for instance, identifies the obligation for states to cooperate with the International Seabed Authority.

${ }^{81}$ The MOX Plant Case (n 78), para 82; Case Concerning Land Reclamation by Singapore in and around the Straits of Johor (Malaysia $v$ Singapore) (Provisional Measures), ITLOS Case No 12 (8 October 2003) para 92.

82 Art 2(2) Kyoto Protocol contains an obligation to cooperate through the IMO on mitigating the climate impact of navigational uses of the sea. MARPOL 71/78, Annex VI was amended in 2006 to extend to greenhouse gas emissions other than exhaust. In July 2011, the 62nd session of the IMO's Marine Environment Protection Committee adopted further amendments in the form of the mandatory Energy Efficiency Design Index for new ships. At its 63rd session in 2012, the Committee considered complementary market-based measures, MEPC 63/23, section 5.

${ }^{83}$ This rationale runs through the jurisprudence of the ITLOS. In the Southern Bluefin Tuna Cases (New Zealand v Japan; Australia v Japan) (Provisional Measures), ITLOS Case Nos 3 \& 4 (27 August 1999), parties were to cooperate on living resources management through the SBT Conservation Convention. Straits of Johor (n 81) suggests means of cooperatively delimiting a maritime boundary. Similarly, Pulp Mills on the River Uruguay (n 52) para 77 envisages states jointly managing a shared river environment; also Gabčikovo-Nagymaros (n 30) paras 140-141. 


\section{PRINCIPLES OF COOPERATION. THE EUROPEAN LAW FRAMEWORK FOR OFFSHORE ELECTRICITY INFRASTRUCTURE}

Establishing international grid governance requires a set of principles. As such, principles are not yet available internationally, they must be generated de novo in appropriate fora, such as the European Union.

\section{A. Absorbing Climate Priorities within European Law}

The EU is indeed obligated to further climate objectives. The EU and its member states are party to both the Framework Convention on Climate Change and the Kyoto Protocol, and they are to meet their quantified emission reduction obligations under the Kyoto Protocol jointly. ${ }^{84}$ As a matter of political prioritization as to how best to achieve these objectives, European secondary law has absorbed the climate regime's goal of mitigation through renewable energies set forth in Article 2(a)(iv) of the Kyoto Protocol. ${ }^{85}$ Directive 2009/28 sets out the legally binding target that 20 per cent of the overall energy consumption in the EU is to be from renewable energies by $2020 .{ }^{86}$ Annex I sets a binding target for each member state to be translated into national renewable energy action plans. ${ }^{87}$ The directive permits flexibility mechanisms which allow member states to support renewable generation outside their borders through 'statistical transfers' and 'joint projects' with another member state or a third state, and two or more may develop joint support schemes. ${ }^{88}$ Much of this renewable energy is expected to be coming from the Northern seas on the basis of a shared offshore grid. ${ }^{89}$

${ }^{84}$ The Kyoto Protocol was approved by Council Decision 2002/358/EC concerning the approval, on behalf of the EC, of the Kyoto Protocol and the joint fulfilment of commitments thereunder, [2002] OJ L 130/1. Art 4 Kyoto Protocol is the international basis for the EU's internal burden sharing. See Joanne Scott, 'The Multi-level Governance of Climate Change', in P Craig and G de Búrca (eds), The Evolution of EU Law (2nd edn, OUP 2011), 805, 807.

85 See Commission (EC), Analysis of Options to Move Beyond 20\% Greenhouse Gas Emission Reductions and Assessing the Risk of Carbon Leakage COM (2010) 265 (26 May 2010).

${ }^{86}$ Directive (EC) No 2009/28 on the promotion of the use of energy from renewable sources and amending and subsequently repealing Directives (EC) 2001/77 and 2003/30/EC, [2009] OJ L $140 / 16$, art 3. This is part of the Europe 2020 strategy to reduce CO2 emissions by 20 per cent and obtain 20 per cent energy from renewables by 2020, European Council, 8/9 March 2007, Presidency Conclusions, Doc 7224/1/07 REV. The EU is on track to meet these targets, Commission (EU), A Roadmap for Moving to a Competitive Low Carbon Economy in 2050 COM (2011) 112 (8 March 2011), p 3.

87 The national target of the UK is 15 per cent.

${ }_{88}$ Directive 2009/28 (n 86) arts 6, 7, 8, 9 and art 11.

89 Commission (EC), Offshore Wind Energy: Action Needed to Deliver on the Energy Policy Objectives for 2020 and Beyond COM 2008(768) (13 November 2008); European Supergrid Report (n 4) paras 20-23. 


\section{B. Developing Principles of Offshore Grid Governance}

In line with these priorities, the EU has been developing principles for offshore grid governance. It is a party to UNCLOS, as are all its member states, ${ }^{90}$ and in the internal division of competences between the EU and its member states implementation of the Convention becomes a European competence to the extent that the Union actually passes legislation on the basis of the Treaty on the Functioning of the European Union (TFEU). ${ }^{91}$ It has relevant competences in the areas of the internal market, ${ }^{92}$ trans-European energy infrastructures, ${ }^{93}$ environmental protection ${ }^{94}$ and now also energy policy. ${ }^{95}$ European legislation under these shared competences (Article 4 TFEU) extends to the EEZs and continental shelves of the member states. ${ }^{96}$ Thus, European harmonization of market access and regulatory regimes for the internal electrical energy market is applicable offshore. ${ }^{97}$ Of particular importance to the offshore grid is Electricity Directive 2009/72 concerning common rules for the internal market in electricity which unbundles ownership of electricity generation from ownership and operation of transmission-systems and from the supply to endcustomers. Regulation 714/2009 requires Transmission Systems Operators (TSOs) to cooperate on regional and European 10-year network development plans for electricity in the framework of the 'European Network of TSOs' (ENTSO-E) and develop 'network codes', which are of critical importance to the offshore grid. Regulation 713/2009 requires national regulators to cooperate on cross-border investments such as the grid within the 'Agency for the Cooperation of Energy Regulators' (ACER), and defines conditions for access to cross-border electricity transmission networks. Yet enhanced efficiency of the electricity energy market will not by itself bring about the interconnected energy infrastructure needed to absorb increasing electricity

90 UNCLOS was approved by Council Decision 98/392 concerning the conclusion by the EC of UNCLOS and the 1994 Agreement relating to the implementation of Part XI thereof, [1998] OJ L 179/1. The Convention is a mixed agreement binding both the EU and its member States. The EU is recognized in UNCLOS, art 305(1)(f), Annex IX, art 1.

91 [2010] OJ C 83/01, entry into force 1 December 2009. See Case C-459/03 Commission v Ireland [2006] ECR I-4635, para 108; otherwise, member states remain competent for implementing the Convention, para 107. UNCLOS then becomes European law falling under the exclusive jurisdiction of the Court, paras 123. However, UNCLOS as European law cannot be directly enforced before EU or national courts, Case C-308/06, Intertanko and Others [2008] ECR I-4057, paras 64-65.

93 TFEU, arts 170-172.

92 TFEU, art 114. December 2009.

${ }_{96}$ Case C-6/04 Commission v United Kingdom [2005] ECR I-9017, para 117.

97 The third internal electricity energy market package of 2009 consists of Directive (EC) No 2009/72 ([2009] OJ L 211/55 and Regulations (EC) No 713/2009, [2009] OJ L 211/1 and 714/ 2009, [2009] OJ L 211/15. For offshore applicability: UK Office of the Gas and Electricity Markets, 'Offshore Electricity Transmission: Further Consultation on the Enduring Regulatory Regime', p 12, < https://www.gov.uk/government/uploads/system/uploads/attachment_data/file/42543/424condoc-offshore-electricity-transmission.pdf $>$. 
generation from renewables. For that purpose, the European Commission's Second Strategic Energy Review (2008) first identified the objective of offshore grid development in the Northern seas, ${ }^{98}$ an objective that has been concretized through subsequent European law-making. In 2010 the Commission tabled the so-called European Energy Infrastructure Package that sets out a list of priority trans-European electricity networks, including an offshore grid across the Northern seas. ${ }^{99}$ In 2011, it proposed a Regulation on trans-European electricity infrastructure under Articles 172, 288(1) TFEU, which was adopted by the European Parliament and the Council in March 2013. ${ }^{100}$ Regulation 347/2013 defines a toolbox for projects of common interests within identified priority electricity corridors, of which the 'Northern Seas offshore grid' is one. ${ }^{101}$ It envisages regional groups formed by member states, with the Commission participating in the planning and governance of such transnational electricity infrastructure. Its common regime includes rules on authorization and, critically for there to be trade in renewables through the grid, the regulation of cross-border cost allocation. Coordination of national authorization processes is envisaged, with each member state designating one national competent authority which will be responsible for facilitating and coordinating the permit granting process for projects of common interest and issuing a comprehensive decision, along with the introduction of time limits and guidelines. The Regulation retains the standard regulatory model of electricity infrastructure based on regulated tariffs collected from the users (the 'user pays' principle). National regulators are to agree on common principles in relation to cost-allocation of interconnection investments and related tariffs. While infrastructure development is to be largely private investment driven, a separate regulation will make supporting European funding available. ${ }^{102}$

The European regulatory framework thus defines relevant principles of grid cooperation, but not their application to individual offshore energy infrastructure projects. This is due to the division of competences between the Union and

98 Commission (EC), An EU Energy Security and Solidarity Action Plan. Second Strategic Energy Review COM (2008) 781 (13 November 2008), approved by the Council (EC), 19 February 2009 (Press release 6670/09).

99 Energy infrastructure (n 4) 25-8. Renewables electricity generation is expected to more than double from 2007 to 2020 of which up to 12 per cent are expected to come from offshore notably the Northern seas, 6, 21.

100 Regulation (EU) No 347/2013 of the EP and of the Council of 17 April 2013 on guidelines for trans-European energy infrastructure and repealing Decision No 1364/2006/EC and amending Regulations 713/2009/EC 714/2009 and 715/2009/EC, OJ L 115/39, so that the first list of projects of common interest to implement this priority corridor can be established by 30 September 2013 .

101 Annex I of the Regulation defines it as an 'integrated offshore electricity grid in the North Sea, the Irish Sea, the English Channel, the Baltic Sea and neighbouring waters to transport electricity from renewable offshore energy sources to centres of consumption and storage and to increase cross-border electricity exchange'.

${ }^{102}$ Commission (EU), Proposal for a Regulation Establishing the Connecting Europe Facility COM (2011) 665 (19 October 2011). The Council agreed on a partial general approach on the proposed regulation at first reading, Doc 10479/12 (7/8 June 2012). 
its member states. Article 171(1), (2) TFEU empowers the Union to determine priorities for trans-European networks and to regulate the relevant principles. ${ }^{103}$ The extent of European harmonization of the national procedures is subject to subsidiarity control under Article 5(3) Treaty on European Union (TEU). ${ }^{104}$ And planning, authorization, and regulation of the grid with the associate cable laying and any offshore installations remain with the member states, as does offshore wind energy policy. ${ }^{105}$ The European legislation on principles for cooperative grid governance thus needs to be complemented by action of the littoral states of the Northern seas. ${ }^{106}$ These in turn have absorbed the objective of increased use of marine renewables in their own national legislation. ${ }^{107}$ The existing national infrastructure comprises radial links connecting offshore generation to the onshore grid and interconnectors. In most states the national Transmission Systems Operators play a significant role in the planning, financing, construction and ownership of offshore infrastructure, while one or more government ministries are responsible for site identification and regulation of offshore generation. ${ }^{108}$ Accordingly, the functional licensing procedure for the right of the TSO to own and operate transmission assets needs to be distinguished from the general planning and consent procedures. ${ }^{109}$

103 cf Commission (EU), Impact Assessment Accompanying the Document Proposal for a Regulation of the European Parliament and of the Council on Guidelines for Trans-European Energy Infrastructure and Repealing Decision No 1364/2006/EC SEC(2011) 1233, 22.

104 [2010] OJ C 83/01, entry into force 1 December 2009.

105 TFEU, art 194(2) guarantees each member state the 'right to determine the conditions for exploiting its energy resources'.

106 From the perspective of the EU, this is also an efficiency consideration as decentralized decision-making allows for experimentation; see B Eberlein, 'Experimentalist Governance in the Energy Sector' in C Sabel and J Zeitlin (eds), Experimentalist Governance in the European Union: Towards a New Architecture (OUP 2010) 61.

107 Art 22 of Directive 2009/28 (n 86) requires member states to submit a report to the Commission on progress in the promotion and use of energy from renewable sources by 31 December 2011, and every two years thereafter. The reports are available at $<\mathrm{http}: / /$ ec.europa.eu/ energy/renewables/reports/2011_en.htm $>$. For use of renewables as part of their climate policies, see also the latest (fifth) national communications of Annex I Parties under the FCCC, $<$ http:// unfccc.int/national_reports/annex_i_natcom/submitted_natcom/items/4903.php >. The key UK legislation is the 2008 Energy Act.

${ }_{108}$ Comprehensively NSCOGI, Working Group 2 Market and Regulatory Issues, Final Report Deliverable 1, Incompatibility of national market and regulatory regimes (13 January 2012), $<$ http://www.benelux.int/NSCOGI/NSCOGI_D1_Final.pdf $>$. In Denmark, France, Germany, Ireland, and Sweden offshore extension of the national onshore grid is the responsibility of the national TSOs, while in Belgium and the Netherlands grid development is the responsibility of the wind farm developer, and the UK tenders the connection of each new offshore wind farm separately, cf Energy infrastructure (n 4), 26; R Tscherning, 'The European Offshore Supergrid and the Expansion of Offshore Wind Energy in Germany, Ireland and the United Kingdom' (2011) 20 European Energy and Environmental Law Review 76, 79.

109 Twenties-project: Offshore Interconnectors: Challenges and Barriers for Consenting (31 May 2011) 11, < http://www.twenties-project.eu/node/18>. 
VI. GOVERNANCE STRUCTURE. THE INTERGOVERNMENTAL NSCOGI AS A REGIONAL GROUP

Regulation 347/2013 envisages regional groups as the governance structure for the transnational electricity infrastructure. This dovetails with the existing practice of the Northern seas bordering states cooperating on marine renewable energy matters within the intergovernmental Pentalateral Energy Forum. In December 2009, these states signed the political Declaration on the North Sea Countries Offshore Grid Initiative, which Norway, as a non-EU member but a key player because of its hydro-storage capacities, joined later. ${ }^{110}$ The NSCOGI envisages a private-investment driven offshore grid with a time horizon of 2030 under a common framework relating to planning, authorization, regulation and investment. It is a forum for cooperation chaired by the participating governments on a rotating basis, assisted by the Benelux secretariat. A Memorandum of Understanding (MOU) signed by the participating states at the end of 2010 operationalizes this offshore infrastructure initiative. ${ }^{11}$ It establishes a regional governance structure aimed at the coordinated exercise by the participating states of their UNCLOS rights with respect to cable laying, installations and marine renewable energy. The MOU involves key public and private stakeholders. These are the states, but also their regulators and the European Agency of Electricity Regulators (ACER), as well as the private operators of the electricity transmission systems through their forum of cooperation (ENTSOE), and the European Commission. ${ }^{112}$ This multi-level and public-private structure serves to enhance the effectiveness and legitimacy of its outcomes, although neither NGOs nor civil society as such are involved. Industry and research have been consulted through the 'Adamowitsch group'. ${ }^{113}$ A Steering Group composed of government and Commission representatives oversees, and a Programme Board consisting of representatives of the Steering Committee and representatives of the national regulators (ACER and ENTSO-E) manages, the work of three working groups. ${ }^{114}$ The mandate of

\footnotetext{
$110<$ http://www.eu-norway.org/news1/Norway-joins-cooperation-on-energy-grid-in-theNorth-Sea $>$.

111 The North Seas Countries' Offshore Grid Initiative, Memorandum of Understanding (MOU), 3 December 2010. <http://www.ewea.org/fileadmin/files/library/publications/researchnotes/MoU_definitief.pdf $>$.

112 See the letters of intent of ACER, Annex 4, the national regulatory authorities, Annex 5, and ENTSO-E, Annex 6 of the MOU (n 111).

113 See EU Coordinator, Fourth Annual Report, 15 November 2011, Annex II (Fourth Report), $<$ http://ec.europa.eu/energy/infrastructure/tent_e/doc/off_shore_wind/2011_annual_report_annex2_ en.pdf $>$. Mr Adamowitsch was appointed in 2007 as European Coordinator for the offshore wind power in Northern Europe (North Sea-Baltic Sea) pursuant to Decision (EC) 1364/2006 laying down guidelines for trans-European energy networks (TEN-E), [2006] OJ L 262/1.

114 The mandates, objectives, timeframes and methodologies of the Working Groups are set out in Annexes 1, 2 and 3 of the MOU.
} 
Working Group 1 is to design grid scenarios, on the basis of existing governmental and industry policies and planning. Centralized decision-making is excluded, ensuring that responsibility for the configuration of the grid will remain with the Transmission System Operators. The second Working Group is concerned with market and regulatory issues such as oversight and access. The third Working Group is to identify where the incompatibility of national regimes on authorizations and planning acts as barrier to fast and coordinated procedures. The governance structure of the MOU ties in with models of decentralized governance increasingly used where the realization of EU objectives depends on the bottom-up coordination of national laws rather than their full harmonization. ${ }^{115}$ The normative output of this governance structure is to be informal. ${ }^{116}$ Non-binding standards may be developed for the coordination of national laws, procedures and planning, and not necessarily their harmonization, which can then be implemented into binding national law by the participants. The MOU's machinery is also set up to integrate the existing legal framework, as defined by European and international law, ${ }^{117}$ particularly on environmental impact assessments in accordance with the Espoo Convention ${ }^{118}$ and the two European Directives. ${ }^{119}$ Carrying out an environmental impact assessment in transboundary projects is also a requirement of customary international law. ${ }^{120}$

The MOU delivered a report at the end of 2012 that recommended continuing the approach of realizing the grid through intergovernmental cooperation. This outcome is not a blueprint, but a suggestion that cooperation between the Northern seas countries should continue to be the way to proceed in developing the electricity infrastructure needed to absorb the renewable capacity. The report comprises reports from each Working Group. That of WG I identifies and compares two scenarios: 'radial'- point-to-point connection of

\footnotetext{
115 Further G de Búrca and J Scott (eds), Law and New Governance in the EU and the US (Hart 2006).

116 cf de Búrca and Scott ibid, 'Introduction' for the relation between new (informal) governance and law.

117 MOU (n 111) Annex 3, pt 1.

118 MOU (n 111) Annex 3, pt 6. The Convention on Environmental Impact Assessment in a Transboundary Context, 25 February 1991, entry into force 10 September 1997, 1989 UNTS 309 (Espoo Convention) is a regional treaty concluded within the UNECE, which the 2001 amendment - not yet force - opens to all UN member states. The EU, its member states and Norway are party to the Convention.

119 Directive No 85/337/EEC of the Council on the assessment of the effects of certain public and private projects on the environment, [1985] OJ L 175/40, and Directive No 2001/42/EC of the $\mathrm{EP}$ and the Council on the assessment of the effects of certain plans and programmes on the Environment, [2001] OJ L 197/30.

120 Pulp Mills on the River Uruguay (n 52), para 204; Responsibilities Opinion (n 30) para 145. The EU is bound by customary international law, Case C-366/10 The Air Transport Association of America and Others, Judgment of 21 December 2011 (nyr) para 101. Customary international law does not determine the content of an EIA, but the Espoo Convention concretizes that obligation for its Parties; cf Pulp Mills on the River Uruguay, para 205.
} 
offshore wind farms and shore-to-shore interconnectors, which implies continuing with uni- or bilateral solutions between countries, and 'meshed'coordinated interconnector design that can form links between three or more states via offshore nodes, which implies multilateral cooperation between the Northern seas states on joint cross-border assets, with the latter enjoying an efficiency advantage. ${ }^{121}$ The report integrates the process of bilateral and multilateral transborder infrastructure cooperation in the Northern Seas including the several shore-to-shore interconnector projects currently being planned or constructed between states. ${ }^{122}$ Thus the Northern seas grid in all likelihood will be realized in a stepwise manner, i.e. hubs of wind energy production will be connected to interconnectors. ${ }^{123}$ To remove barriers for realizing such a meshed grid, Working Group II has drawn up a set of principles to be used as guidelines for the development of cross-border infrastructure. The principles cover issues such as planning, grid design, financing, operation of assets, ownership of assets and system charges. The aim is to move towards a more common approach on the necessary investments. As there are currently no arrangements at international, European or national level for paying for integrated assets combining interconnection and offshore generation, WG II proposed that the national TSO finances infrastructure and that the relevant regulator approves efficient costs. ${ }^{124}$ For trading in renewables there would need to be common models on support schemes for offshore renewable energy and agreed solutions on how to apportion costs for crossborder projects between states. In its future work, the WG will take account of the mechanisms that the novel European infrastructure Regulation 347/2013 contains. ${ }^{125}$ In order to remove barriers on planning and authorization, WG III

121 NSCOGI (Initial Findings), Working Group I Grid configuration, Final Report (16 November 2012), <http://www.benelux.int/NSCOGI/NSCOGI_WG1_OffshoreGridReport.pdf>. On p 58, the report confirms the results of the earlier study OffshoreGrid: Offshore Electricity Infrastructure in Europe, October 2011, prepared by 3e, a team of seven industry partners, < http:// mainstream-downloads.opendebate.co.uk/downloads/OffshoreGrid_report_complete_[1].pdf $>$. See also OFGEM, Memorandum (ESG 09), European Supergrid Report (n 4).

122 The WG 1 Report lists these by country. See also the lists contained in European Supergrid Report (n 4) Annex II, 'Different Supergrid Proposals and Work Streams in 2011', and in Offshore Transmission Technology (n 10) 27-34. Links are planned between Norway and the UK (Scotland), UK Department of Energy and Climate Change, 'One North Sea: Joint Ministerial Statement on Climate Change and Energy Security', Press Release 2010/096; Scottish Government, Memorandum (ESG 26) for European Supergrid Report, and between Ireland and the UK.

${ }^{123}$ NSCOGI WG 1 Report; OffshoreGrid (n 121) 14. For early design suggestions see Working Group for offshore and onshore grid development in Northern Europe, Modular design for the Development of the Offshore/Onshore Grid in the North Sea (March 2009), <http://ec.europa.eu/ energy/infrastructure/tent_e/doc/off_shore_wind/2009_off_shore_grid_workshop_opening.pdf $>$.

${ }_{124}$ NSCOGI, Working Group 2 Market and Regulatory Issues, Discussion Paper Deliverable 5, Possible Market Arrangements for Integrated Offshore Networks (13 March 2013), < http://www. benelux.int/NSCOGI/NSCOGI_Discussion_Paper_Possible_Market_Arrangements_Integrated_ Offshore_Networks.pdf $>$.

${ }^{125}$ NSCOGI,Working Group 2 Market and Regulatory Issues, Final Report Deliverable 2, Recommendations for Guiding Principles for the Development of Integrated Offshore Cross-border 
has initially drawn up a set of general principles for NSCOGI states to use as guidelines for the authorization of cross-border transmission infrastructure. ${ }^{126}$ The objective is to coordinate rather than harmonize national procedures. The Espoo Convention is identified as an effective standard for conducting of environmental impact assessments of transboundary grid projects, engaging both 'parties of origin' in whose territorial sea or EEZ construction will take place and other parties which may be affected by the project in some way. ${ }^{127}$ The Espoo Convention applies 'as a minimum' at the project level (Article 2 (7)), and its additional Protocol on Strategic Environmental Assessment obliges Parties to undertake environmental impact assessments on policies, plans and programmes as well. ${ }^{128}$ The Espoo Convention cannot be applied directly since cable laying is not listed in its Appendix I, ${ }^{129}$ but Parties could agree specifically that it apply to grid projects in two ways. Parties may agree to treat a non-listed activity as if it were listed because it is likely to cause a significant adverse transboundary impact. Criteria for identifying such impact are set forth in Appendix III (Article 2(5)). Implementation of the Convention can also be by separate international agreement guided by the elements listed in Appendix VI (Article 8). A precedent for such ad hoc agreed application of the Convention is the Baltic 'Nordstream pipeline'. ${ }^{130}$ Finally, Appendix I could be amended to include submarine cables in the normal amendment procedure (Articles 10, 14).

This initial outcome was endorsed in December 2012 by the Energy Ministers of the NSCOGI participants who recognized that this type of regional cooperation was needed to bring about investment in cross-border infrastructure. ${ }^{131}$ Ministers asked the relevant actors-network operators, ENTSO-E, ACER and national regulators - to continue working with governments and the Commission on possible future grid configurations for the Northern seas, and to develop further concretizing proposals to address the regulatory, market and planning barriers.

Infrastructure (23 November 2012), <http://www.benelux.int/NSCOGI/NSCOGI_WG2_ HighLevelPrinciplesRevisedFinal.pdf $>$.

126 NSCOGI, Working Group 3 Procedural Guidelines, Final Report Deliverable 2, Procedural Guidelines as a Recommendation to the National Competent Authorities (without date), $<$ http:// www.benelux.int/NSCOGI/NSCOGI_WG3_ProceduralGuidelines.pdf $>$.

${ }^{127}$ NSCOGI WG 3 Report, 9.

128 The Protocol on Strategic Environmental Assessment to the Espoo Convention, 21 May 2003, entry into force 11 July 2010, ECE/MP.EIA/2003/2, is now in force for the EU, its member states, and Norway.

${ }^{129}$ The 'list of activities' in Appendix I as amended, mentions 'large diameter pipelines' (No 8), 'overhead electrical power lines (No 20), and 'wind farms' (No 22), but not submarine cables.

130 The Russian Federation has signed but not ratified the Espoo Convention. Yet for the purposes of the Nord Stream project, it has been acting as a 'Party of origin' as far as it considers it possible according to its legislation.

$131<$ http://www.benelux.int/NSCOGI/NSCOGI_PressReleaseDecember2012.pdf > . 


\section{INTEGRATING INTERNATIONAL, EUROPEAN AND NATIONAL LAW}

Cooperative governance of offshore electricity infrastructure in the Northern seas depends on the combined effect of international, European and national law. This type of interaction does not easily fit any of the received conceptions of the relationship between these legal orders. Concepts of international law such as fragmentation, ${ }^{132}$ the sectoral specialization of treaties, ${ }^{133}$ or a merely general interaction between treaties, ${ }^{134}$ share certain presuppositions, most importantly the essential isolation of each legal order and the definition of its static relationship with others through 'conflicts' principles that are ultimately judicially determined. These twin presuppositions also underlie the doctrine of the autonomy of European law from international law as understood by the $\mathrm{ECJ},{ }^{135}$ and the corresponding doctrine of the autonomy of international law from regional law as understood by the ICJ. ${ }^{136}$ The reality of the shared offshore electricity infrastructure in the Northern seas is, however, not compatible with these presuppositions. Here, the relevant international treaties on the climate and the oceans, European law and national law are not isolated from each other. Nor do they interact in an unspecified way. Rather they become functionally integrated in an overarching scheme: each legal order fulfils a specific and indispensable function for dynamically realizing the shared objective of the grid.

This integration is not the work of a central authority. Rather each legal order evolves through autonomous action to fulfil its respective function. Such action bears first of all on the conception of its relationship with external law as being one of complementarity for the achievement of common objectives. This is true for the international climate regime which does not purport to achieve the climate priorities of the international community directly, but depends on other elements of the international law framework, particularly the major preexisting law-making treaties such as UNCLOS. ${ }^{137}$ The law of the sea in turn absorbs the novel climate priorities set by the international community and realizes them within its own system of governance and through principles

132 See Report on Fragmentation (n 76), Conclusions, mitigated by the assumption that international law overall forms a system, paras 1, 17-23.

${ }^{133}$ For such an understanding of UNCLOS and the climate regime see D Rothwell and $\mathrm{T}$ Stephens, The International Law of the Sea (Hart 2010) 168.

134 See A Boyle, 'Further Development of the Law of the Sea Convention: Mechanisms for Change', (2005) 54 ICLQ 563, 578-84.

${ }^{135}$ For instance Opinion $1 / 09$ on the international European and Community Patents Court, [2011] ECR 1137; Joined Cases C-402/05 P and C-415/05P, Kadi [2008] ECR 6351. See generally J Klabbers, 'The Validity of EU Norms Conflicting with International Obligations' in E Cannizzaro, P Palchetti and R Wessels (eds), International Law as Law of the European Union (Nijhoff 2012) 111.

${ }_{136}$ Questions Relating to the Obligation to Prosecute or Extradite (Belgium v Senegal), Judgment of 20 July 2012 (nyr) para 111.

137 Following established terminology, law-making treaties protect common concerns of the international community, rather than just creating reciprocal obligations for states; see J Pauwelyn, Conflicts of Norms in Public International Law (Cambridge University Press 2003) 52-89. 
of interpretation. The alternative mechanism is law-making through the treaty's machinery, through implementing treaties, or any other suitable arrangements. ${ }^{138}$ But international climate priorities also reach through to any regional organization to which states have transferred relevant responsibilities, and which may draw on its law-making machinery for absorbing and realizing the international community's objective. Here, for example, European secondary law has developed principles that underpin the cooperative harvesting of marine renewable energy through a shared grid. Finally, international climate priorities reach through to the level of national law, where each of the several legal orders is coordinated by states through appropriate regional intergovernmental mechanisms that can then engage not just the states themselves but also with other competent public actors and key private actors.

This functional integration of international law, European law and national law in the pursuit of ocean space governance is transferable to other instances where international law, European and national laws need to work together to bring about an internationally defined objective. ${ }^{139}$ That is not to say that conflicts between international law and (primary) European law cannot arise, only that these instances can be managed through appropriate secondary lawmaking that seeks to ensure their integration. ${ }^{140}$

\section{CONCLUSIONS}

The article has argued that the objective of shared large-scale offshore electricity infrastructure for marine renewable exploitation as envisaged for the Northern seas can be realized through the functional integration of international law, European law and national law. This integration means that each of these legal orders plays a specific role in achieving the common objective. The international climate regime determines the impetus for establishing offshore electricity grids as a means of mitigating climate change through renewable energy use. The law of the sea defines the competent state for each grid element. European law generates principles for their cooperation, which are then implemented through national law of both EU member states and non-member states coordinated within the intergovernmental mechanism

\footnotetext{
138 cf B Simma, 'Foreign Investment Arbitration: A Place for Human Rights?' (2011) 59 ICLQ 573, 581-4 (investment contracts for achieving of human rights objectives in investment law).

139 For examples ranging from solidarity to non-discrimination to the environment see Sabel and Zeitlin (n 106).

140 For instance, the 'constitutional' conflict between the international anti-terrorism objective and European fundamental rights has been managed through secondary law-making both at UN and European levels, see Opinion of Advocate General Bot of 19 March 2013 in Joined Cases C-584/10 P, C-593/10 P and C-595/10 P, Kadi II, and Council Regulation (EU) No 1286/2009 amending Regulation (EC) No 881/2002 imposing certain specific restrictive measures directed against certain persons and entities associated with Usama bin Laden, the Al-Qaida network and the Taliban, [2009] OJ L 346/42.
} 
of the NSCOGI. Each of these legal orders fulfils its responsibility through autonomous action and, as a result, each changes structurally.

But the legal ordering of shared offshore electricity grids also is a salient example of a broader trend in the interaction of international, European and national law. That trend does not so much fit any of the general theories which are essentially based on the autonomy of in particular European law, and which focus very much on court-resolved conflicts between them. In reality, increasingly international, European and national law work together. Global energy and environmental objectives have been particular drivers of this trend, but it has also manifested itself with respect to policies ranging from antiterrorism to international monetary stability. This trend illustrates the way in which the functional integration of international law, European law and national law is emerging as a distinct legal institution in its own right, separate and distinct from the various legal orders themselves. ${ }^{141}$

${ }^{141}$ See N MacCormick, Institutions of Law (OUP 2007) 31-4. He primarily focuses on the legal institutions of the constitutional state, but acknowledges that legal institutions can also form outside of this context. 